\title{
The Tartu School and Catalan Scholarship: A Book Review Article of New Work in Reception and Communication Studie
}

\author{
Christopher Larkosh \\ University of Massachusetts Darthmouth
}

Follow this and additional works at: https://docs.lib.purdue.edu/clcweb

(3)

Part of the Comparative Literature Commons, and the Critical and Cultural Studies Commons

Dedicated to the dissemination of scholarly and professional information, Purdue University Press selects, develops, and distributes quality resources in several key subject areas for which its parent university is famous, including business, technology, health, veterinary medicine, and other selected disciplines in the humanities and sciences.

CLCWeb: Comparative Literature and Culture, the peer-reviewed, full-text, and open-access learned journal in the humanities and social sciences, publishes new scholarship following tenets of the discipline of comparative literature and the field of cultural studies designated as "comparative cultural studies." Publications in the journal are indexed in the Annual Bibliography of English Language and Literature (Chadwyck-Healey), the Arts and Humanities Citation Index (Thomson Reuters ISI), the Humanities Index (Wilson), Humanities International Complete (EBSCO), the International Bibliography of the Modern Language Association of America, and Scopus (Elsevier). The journal is affiliated with the Purdue University Press monograph series of Books in Comparative Cultural Studies. Contact: <clcweb@purdue.edu>

\section{Recommended Citation}

Larkosh, Christopher. "The Tartu School and Catalan Scholarship: A Book Review Article of New Work in Reception and Communication Studie." CLCWeb: Comparative Literature and Culture 13.4 (2011): <https://doi.org/10.7771/ 1481-4374.1877>

This text has been double-blind peer reviewed by $2+1$ experts in the field.

The above text, published by Purdue University Press @Purdue University, has been downloaded 336 times as of $11 /$ $07 / 19$.

This document has been made available through Purdue e-Pubs, a service of the Purdue University Libraries. Please contact epubs@purdue.edu for additional information.

This is an Open Access journal. This means that it uses a funding model that does not charge readers or their institutions for access. Readers may freely read, download, copy, distribute, print, search, or link to the full texts of articles. This journal is covered under the CC BY-NC-ND license. 


\section{PURDUE}

UNIVERSITY PRESS <http://www.thepress.purdue.edu>

\section{CLCWeb: Comparative Literature and Culture}

ISSN 1481-4374 <http://docs.lib.purdue.edu/clcweb> Purdue University Press (CPurdue University

CLCWeb: Comparative Literature and Culture, the peer-reviewed, full-text, and open-access learned journal in the humanities and social sciences, publishes new scholarship following tenets of the discipline of comparative literature and the field of cultural studies designated as "comparative cultural studies." In addition to the publication of articles, the journal publishes review articles of scholarly books and publishes research material in its Library Series. Publications in the journal are indexed in the Annual Bibliography of English Language and Literature (Chadwyck-Healey), the Arts and Humanities Citation Index (Thomson Reuters ISI), the Humanities Index (Wilson), Humanities International Complete (EBSCO), the International Bibliography of the Modern Language Association of America, and Scopus (Elsevier). The journal is affiliated with the Purdue University Press monograph series of Books in Comparative Cultural Studies. Contact: <clcweb@purdue.edu>

Volume 13 Issue 4 (December 2011) Book Review Article 15 Christopher Larkosh,

"The Tartu School and Catalan Scholarship:

A Book Review Article of New Work in Reception and Communication Studies"

<http://docs.lib.purdue.edu/clcweb/vol13/iss4/15>

Contents of CLCWeb: Comparative Literature and Culture 13.4 (2011)

<http://docs.lib.purdue.edu/clcweb/vol13/iss4/> 


\section{Christopher LARKOSH}

\section{The Tartu School and Catalan Scholarship: A Book Review Article of New Work in Reception and Communication Studies}

In comparative literary and cultural studies, the question continues to circulate as to what is it we are comparing, that is, what is the relevance of the general linguistic, cultural, and disciplinary limits of any given scholar's area of observation and how does a group of scholars arrive at a general understanding of these limits in order to imagine themselves as a scholarly community, however momentary or tentative that shared commitment may be? Two recently published issues of scholarly journals come to a divergent set of answers to these questions, but with areas of overlap which still make for a thought-provoking discussion on the borders of both established and emerging disciplines - reception studies and communication studies - in the humanities and social sciences today. The first collection I am discussing - La Réception entre théories de la littérature et théories de la culture (Ed. Stefano Montes, Katre Talviste, and Tanel Leposo, 2007) - was published as a special issue of the journal Studia Romanica Tartuensia at the University of Tartu, once one of the principal centers of literary scholarship in the former Soviet Union owing to the work of the Yurii Lotman. This collection of essays in French on the concept of reception between theories of literature and those of culture not only repositions of the "Tartu School" as a meeting point for a renewed discussion of literary and cultural theory, but also calls forth, however inadvertently, a call for the cultural reinvention for universities in any number of post-imperial spaces, wherever around the globe they may be found. The discussion revolves around the question of what ways of reconfiguring the academic community will supplement or supplant those that marked the previous period, whether theoretical, linguistic, or cultural? In present-day Tartu, the scholars assembled in this volume inscribe this space with a different set of cultural and linguistic coordinates, one no longer exclusively at the edge of a geopolitically dominant Russian language and culture, but also of Romance languages, literary study and theory, with French acting as the de facto vehicle of communication, albeit with both other Romance and non-Romance language cultures still making their inevitable appearance as part of an at least partially repositioned comparative cultural framework under the clearly identifiable rubric of Francophonie. Such a gathering of scholars would no doubt find itself at home anywhere in the French-speaking world and the eastern edge of the European Union, close to the presently redrawn borders of post-Cold War Russia, is by no means an exception, where a number of nation-states now profess to be official parts of the Francophone world, whether in the Baltic States, South Europe, Bulgaria, or the Caucasus, or Romania where French is remains a language of scholarship.

Whatever the present geopolitical context, the discussion at hand is about reception, a concept which - while still a concrete and historically bound theoretical point of reference of the late twentieth century shaped by the work of such scholars as Hans Robert Jauss and Wolfgang Iser - is evidently still very much on the move and perhaps is even all the more easily understood in this context as that ever-shifting body of materials and media that each of us is exposed to or has access to on the basis of a continually expanding or diminishing set of linguistic, cultural, and geopolitical limitations. As the editors state in their Preface:

Reception is an activity, and at the same time a point of contact of all disciplines that question humankind. Although it is an activity in which we all participate integrally and collaboratively, without the possibility of escaping or suspending it, reception remains a difficult object to study in any concrete and objective way: its never-ending movement does not allow it. It is necessary to surrender to this fact from the outset in order to respond to it, as this surrender is only partial. If we anchor ourselves totally in this initial aporia, we can gain some clear advantage from the fact that reception is in contact with numerous disciplines: it permits us to bridge theory and practice, writing and reading, identity and alterity, literatures and cultures. For this reason, it is enough, to use a spatial metaphor, to shift the point from one centered on the self and its origin to one at its limit, situating it between those of departure and arrival. (unless indicated otherwise, all translations are mine)

La réception est une activité et, au même temps, un point de contact de toutes les disciplines s'interrogeant sur l'Homme. Bien qu'elle soit une activité à la quelle nous participons tous intégralement et conjointement, sans possibilité de fuite ou de suspension, la réception reste un objet difficile à étudier concrètement et objectivement : son mouvement incessant nous l'interdit. Il faut d'abord se rendre à ce constat pour répliquer ensuite, sans hésitation aucune, que cette reddition à son dynamisme n'est que partielle. Si nous nous ancrons totalement dans cette aporie initiale, nous pouvons tirer un avantage certain de cette capacité de la réception de toucher plusieurs domaines: 
elle permet en effet de jeter un pont entre la théorie et la pratique, l'écriture et la lecture, l'identité et l'alterité, les littératures et les cultures. Il suffit alors, pour utiliser une métaphore spatiale, de renverser le point de point centré sur Soi et sur l'Origine pour le déplacer vers le Seuil, pour se situer entre le Départ et l'Arrivée. (7)

As the above quotation is circulated once again in the volume and thus is implicated in a presumably endless cycle of reception, the question still remains as to what extent the capacity of such reception - especially as understood to act as a point of contact and bridge the gap between presumably separate disciplinary domains - is truly as limitless in its possible permutations and possibilities as one might imagine. Even a broad set of cultural starting points becomes subject to the necessity for a common language of scholarship, whether French or English or any other organizational vehicle of the academic community, and with it an all-too-often unavoidable set of canonical readings which provides the conditions of a common basis for communication. Even in the most multilingual and multicultural literary environments, each of us remains, at least to some extent, always already subject to our own histories of reception, no matter how open we may be at any given moment to that which is new to us, perhaps even in a different language with which we are less familiar. This map of shared points of reference will no doubt set the conditions and terms of how we arrive not only of the presumably wellworn theoretical concept identified here as reception, but also of reception as a continual and unavoidable cultural and linguistic praxis.

The attempt on the part of the editors of and contributors to La Réception entre théories de la littérature et théories de la culture to encompass wide-ranging and disparate disciplinary points of communication is admirably taken on in this quote. And this is the case especially in the discussions of translation as an essential dimension of reception and that holds out the ever-incomplete possibility of passage beyond the limitations of self and origin toward that point where those of others begin. Nowhere is this threshold more palpable in the collection than in those moments where the culture of the language of the scholarly community is displaced for another, for example in Olivier Kachler's essay on the translation into French and subsequent reception in Parisian literary circles of the Russian poet Alexander Blok's poem "Dvenadsat'" ("Twelve") or in Claudia Braga's article on the reception of French melodrama in nineteenth-century Brazil. Both serve the important function of pointing toward that wide terrain of cultural and linguistic otherness that lies beyond the limits of not only the French language and culture as centered in a mainly Parisian literary theoretical milieu, but also the Eurocentric limitations that continue to place their conditions upon the development of intellectual discourse both in and beyond Western Europe. After all, even if the corpus of literary and cultural points of reference is still in the process of being supplemented both within and beyond any single language-based community of humanities scholars, there is always the danger that the configuration of references will end up drawing not a interconnected web of references of divergent cultural and linguistic origins, but, rather, yet another wheel-and-spoke model of literary reception and referentiality with any one of the traditional literary capitals of the past (Paris, London, inter alia) still clearly at the center.

In this particular case, the theoretical references still place the geographical hub of this discussion not in Tartu (any reference to literary and cultural relations with the local Estonian culture is as noticeably absent as it might have been for many of those Russian scholars based here during the Soviet era), but now the imperial capital appears no longer to be Moscow but, perhaps all-too-predictably, Paris. Admittedly, many literary and cultural scholars remain dependent on a well-known selection of theoretical, philosophical, and literary texts not only to keep their cultural bearings intact - perhaps just one cherished facet of what the editors identified in the Preface as "self and origin" - but also to ensure their increasingly precarious capacity to communicate with others in rapidly globalizing professional circles. At the same time that many experience cultural and linguistic vertigo, they still await something as of yet that might be experienced as even unheard of or, dare I say, "new." But how can it be expected to arrive if it is constantly crowded out by the repetition of the same? This is not to say that there are no key moments where the tightly knit concentric circles of Parisian and/or Eurocentric intertextuality are not momentarily interrupted. One need only turn to the first lines of the article by Stefano Montes entitled "Les Structures de la reception et les passions du traducteur. D'une note de Levi à une sémio-anthropologie de la traduction" (215-71) for what might well be considered a counter model to those literary and cultural mappings of reception and translation which solidify traditional centers of power and authority and serve thereby to maintain consensus about where our common 
cultural margins may lie. In a piece presumably on Primo Levi's translation from German to Italian of Franz Kafka's novel The Trial, Montes nonetheless begins with two culturally disparate epigraphs: one by the Russian linguist Roman Jakobson and the other by the Congolese author Sony Labou Tansi. Montes proceeds to offer a rationale for this juxtaposition of apparently divergent literary and academic references as a point of departure for his discussion: "Why quote Labou Tansi and Jakobson? Why bring a Congolese writer and a Russian linguist together in an essay on Primo Levi and translation? Quite simply for the pleasure of seeing two 'authors' on the same page who never met each other in their lifetimes, for the pleasure of projecting onto the same page, in an abusive and personal way, a writer and a linguist. And pleasure, one knows, does not ask for explanations" ("Pourquoi citer en épigraphe Labou Tansi et Jakobson? Pourquoi rapprocher un écrivain congolais et un linguiste russe dans une étude sur Primo Levi et la traduction? Tout simplement pour le plaisir librement de voir dans la même page deux 'auteurs' qui ne se sont jamais connus de leur vivant, pour le plaisir de projeter, de manière abusive et personnelle, dans une même page un écrivain et un linguiste. Et le plaisir, on le sait, ne demande pas d'explications" [215]).

While such explanations might be necessary to some, for this reader at least, no justification was necessary. In fact, this was perhaps precisely the moment that many readers like myself had been waiting for: one in which the volume before them made a clear break with established linguistic and cultural patterns of referentiality to make room for a different kind of cultural politics, one in which the French language is merely the vehicle for a wide range of transformative proposals arranged not in the order of their proximity to a agreed-upon center, but a linguistic register that actually allows for a radical remapping beyond the limits of self and origins toward the very threshold of otherness that this volume sets as its presumable destination. This remapping is only intensified in the following discussion of Levi, Italian author and concentration camp survivor, as he returns to the work of Kafka: Levi transformed his own traumatic lived experience while translating the literary work of another and thereby generated a rich and intense discussion on the act of literary translation, one to which Montes also makes a significant contribution in his study. In this context, it is hardly surprising that the work of Gilles Deleuze should resurface here, not merely because he, in collaboration with Félix Guattari, is a recognized Kafka scholar in his own right, but also because the way to Kafka via Levi as it is charted here allows for numerous points of departure and approach, not only those that pass through a common, consensual and yes, "French" set of references (227). Ultimately, it is precisely in this way that, whether through Levi and/or Kafka or through Labou Tansi and/or Jakobson, "one assures the possibility of a new interpretation" ("on s'assure la possibilité d'une nouvelle interprétation" [268]).

With the recognition in mind that an expanded, multilingual field of reference opens, even if it does not necessarily assure, the possibilities for new cultural interpretations that I turn to the second collection under review, the Catalan Journal of Communication \& Cultural Studies (Ed. Enric Castelló, Josetxo Cerdán, Jordi Ferré, and Hugh O'Donnell, 2009). With an editorial board based primarily at the University of Rovira i Virgili, it is nonetheless published in English for an international audience and the notes with regard to contributions make clear that submissions "must be written in a clear and concise style in English" (3). The rationale for this choice to publish in English can be found in the editorial entitled "A Journal at the Right Time" (5-8) in which the editors state that "we had the feeling that scholarship in the cultural and social disciplines in Catalonia had been too inward looking for too long, and the time had come to raise our heads and look around us" (5).

For scholars familiar with Catalan culture and language, there is already no question that this Mediterranean language-culture of around ten million speakers has had much to contribute to a number of international academic discussions for some time, especially in relation to the social contexts listed in the introduction: "the stateless national condition, bilingual or multilingual societies, emerging media and cinema industries, coexistence of cultures, minority language media, competing discourses of social identity, formal (and informal) cultural and media policies, migratory and trans-national discourses, and so on" (6). This relevance to cultural and linguistic spaces far beyond its conventional geographic boundaries is not limited to those other nations to which it is invariably compared in recent international academic research on the topic: i.e., Scotland or Québec. In this volume, the contributions of Scottish-based researchers such as Philip Schlesinger, Peter Lynch, and Hugh O'Donnell once again encourage this by-now familiar comparison with Scotland. At the same time, other autonomous regions within the Spanish State, such as Euskadi and Iberian Galicia, continue to figure somewhat 
less prominently alongside Catalonia in such comparative studies of linguistic and cultural autonomy. For this reason, John Payne's comparative review of two recent cultural histories - one on Catalonia and another on Basque Country - is a welcome addition and points toward an expanded set of spaces that could be brought into this discussion.

With this in mind, it is an even more promising sign to see the article by Iolanda Tortajada and Cilia Willem on media representations of an ethnic minority such as the Catalan Roma in the volume. Indeed, as we continue to look at marginalized languages and cultures through the lens of Catalonia, our responsibility for the Other - as elaborated by Emmanuel Levinas and reinvoked in the collection by Leonarda García Jiménez and Susana Martínez Guillem in their article on the identity of communication studies (15-28) - may point us in unexpected directions as we return to discussions of other stateless cultures. For example, any discussion of linguistic and cultural autonomy in Québec would do well to consider the condition of linguistic and cultural rights not only in relation to First Nation communities in Québec and the rest of North America (Canada, the U.S., Mexico), but also of those of refugee and immigrant communities as well. With this research focus on internal minority populations in mind, Marta Montagut's critique of the role of current market forces and European Union standardization of university programs in communication studies (47-65) underscore once again the need for academic disciplines whose research agendas serve not only a corporate economic function, but a social and cultural one as well.

Jordi Xifra's article on Catalan culture - "Catalan Public Diplomacy, Soft Power and noopolitik: A Public Relations Approach to Catalonia's Governance" 65-87) - and John Arquilla's and David Ronfeld's concept of "noopolitik" and in conjunction with Joseph Nye's notion of "soft power" offers a valuable introduction to the challenges that stateless cultures face as they attempt to project their cultural politics onto an international stage on which full-fledges independent nation-states still retain a distinct advantage. Whether through well known sports teams like Barça or Catalan Communities Abroad or diplomatic ties with other governmental entities, the idea of popularizing Catalonia as a global brand proceeds, in Xifra's view, with varying levels of success. The discussion is extended in Josep Gifreu's article on the Catalan communicative space and its role in fostering a distinct cultural and linguistic identity politics - be it through traditional forms of print or visual media, or through the internet - an informational development that has exponentially expanded access to Catalan media culture beyond present geopolitical divisions and into the world with newspapers, television, radio, and other forms of Catalan-language media now available virtually anywhere in the world at the click of a mouse.

The article on the Catalan television station TVE Catalunya by Mar Binimelis, Josetxo Cerdán, and Miguel Fernández reiterates the above point by stating that "fifty years on, TVE Catalunya not only draws on collective memories of the past stored in its archives but also vindicates itself as belonging to the democratic inheritance of the country. Now is the time, perhaps, to consider television in CataIonia in a new light" (103). While Andreu Casero draws attention to the persistent lack of coordination between the three autonomous regions that comprise the Països Catalans (Catalonia, the Valencian Community, and the Balearic Islands), little or no mention is made not only of how traditionally Catalan-speaking regions outside Spain - such as Languedoc-Roussillon in southern France or the Sardinian city of Alghero - would figure into a Catalan communications strategy for the twenty-first century, but also how Catalan language media will be carried beyond conventional cultural boundaries to other parts of the Iberian Peninsula, Europe, the Americas, and to the rest of the world.

What is perhaps the most exciting conclusion that results from reading these two edited collections in tandem is how both minority language communities and international academic networks continue to arrive at alternative linguistic pathways to reach new audiences and create new dialogues and interpretations of culture. The role of translation and multilingualism only reinforces the sense that there is no single linguistic pathway that can do the job alone, be it a global academic language such as French or English, or one like Catalan with only a few million speakers across Europe. Scholarly communities will continue to reconfigure themselves as new geopolitical realities shift the focus away from the major national cultures of Europe and Anglophone North America and onto other regions of the globe such as Africa, Latin America, Asia, and the Pacific. That may not only be the future of English or French - to say nothing of Chinese, Hindi, Arabic, Portuguese, or Spanish - but possibly the future of less-spoken languages like Catalan or Estonian, as they too prepare for an increased level of 


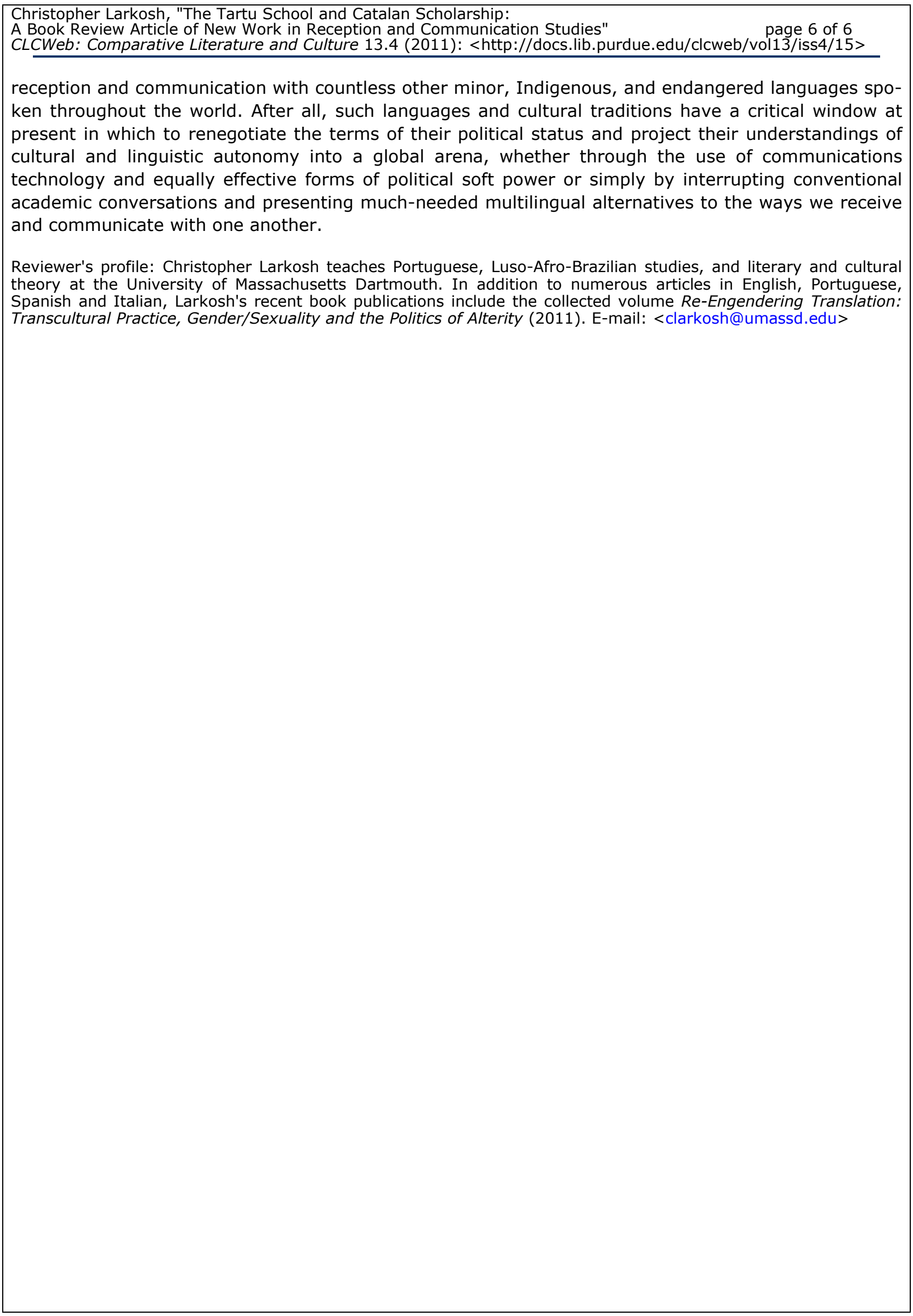

